\title{
LEPT, A SIMPLIFIED APPROACH FOR ASSESSING KARST VULNERABILITY IN REGIONS BY SPARSE DATA: A CASE IN KERMANSHAH PROVINCE, IRAN
}

\author{
Kamal Taheri \\ Groundwater and Karst expert in Kermanshah Regional Water Authority, Kermanshah, Iran, \\ Taheri.kamal@gmail.com
}

Milad Taheri

Bu-Ali Sina University, Hamadan, Iran, milad.thr@gmail.com

Fathollah Mohsenipour

Head of groundwater study group in Kermanshah Regional Water Authority, Kermanshah, Iran

\begin{abstract}
There are a variety of widely used methods for porous aquifer protection to assess the vulnerability of groundwater resources, such as DRASTIC; Depth to water, net Recharge, Aquifer media, Soil media, Topography, Impact of vadose zone, and hydraulic Conductivity, SINTACS; depth to ground water (S), effective infiltration (I), unsaturated zone attenuation capacity $(N)$, soil attenuation capacity $(T)$, hydrogeologic aquifer characteristics (A), hydraulic conductivity range (C) and hydrological role of the topographic slope (S). And GOD; Groundwater occurrence, Overlying lithology, and Depth of groundwater. However, some more limited methods (including EPIK; Epikarst development, Protective cover, Infiltration conditions and Karst network development, PaPRIKa; Protection of karst Aquifers based on their Protection, Reservoir, Infiltration and Karstification type and COP; Concentration of flow, Overlying layers, and Precipitation regime) are also suggested for karstic aquifer vulnerability analysis. The latter methods are applied using different parameters such as karst network development, depth of karstification, and protective cover. Due to the nature of the data, these methods are highly affected by local and regional climate conditions. Data gathering for these methods is difficult, time consuming and needs a full understanding of karst systems. Data shortages, especially those related to karst formations in some parts of the world including the west part of Iran, and crucial demands for utilizing water resources demonstrate a great appeal to find a representative method for evaluation of these regions. Conventional methods of karst aquifer evaluation cannot be properly applied in the absence of a required karst
\end{abstract}

data base; therefore, there is a need for a method that could be applied with the least amount of available data. The LEPT method introduced in this paper is a simple approach which provides rough evaluation of the general information gathered from karst areas of the west of Iran combined with field experiments. This method, which utilizes four parameters to assess the vulnerability of karst aquifers, was applied to the karst areas of Kermanshah (a province in the west of Iran) for the first time. Results of this approach categorize karst plains into four zones with very high, high, low and very low sensitivity in terms of their vulnerability to environmental impact. These classes are positively correlated with field information.

\section{Introduction}

Despite its undeniable role in drinking water supply for both rural and urban areas, karst aquifers are highly vulnerable to contamination. In some cases, presence of thin or no soil cover, shallow depth/thickness of karst aquifer overburden (epikarst zones) and direct point recharge via swallow holes make these water resources more susceptible to contamination by a variety of anthropogenic pollutants. On the other hand, because of the high groundwater velocity, short residence time of pollutants in karst aquifers affects the processes of contaminant attenuation in karst systems (Goldscheider, 2005). This is especially true in bare or thinly covered karst terrains. Comprehension of the level of sensitivity of karst aquifers to contamination and provision of a thorough karst management strategy can establish an effective framework for planning and scheduling protection programs.

Several researchers have shown keen interest in groundwater protection since Margat (1968) and Albinet 
and Margat (1970) first introduced the concept of the vulnerability of groundwater to contamination (Foster and Hirata, 1988; Adams and Foster, 1992; Drew and Hotzl, 1999; Zwahlen, 2004). As a result of these investigations, some methods have been introduced for mapping karst aquifer vulnerability, including DRASTIC (Aller et al., 1987); GOD (Foster, 1987); AVI (Van Stempvoort et al., 1993) and SINTACS (Civita, 1994).

Although there are specifically designed methods to evaluate the vulnerability of karst systems, in some cases, these methods have been modified due to highly heterogeneous and anisotropic characteristics of karst aquifers. These modified methods could not be conveniently and broadly used in every karst system because of their vast input data requirement. The absence of climatic and/or hydrogeological data as well as difficult and expensive ways of data gathering in these fields stimulate a demand for establishing new methods that could be applied with the least available data and still lead to acceptable interpretations.

Several methods were specifically developed for the assessment of vulnerability in karstic areas. These include: COST action 620 or the European approach to vulnerability and risk mapping for the protection of karst aquifers (Zwahlen, 2004; European Commission, 2000; Daly et al., 2002; Goldscheider and Popescu, 2004); EPIK (Doerfliger and Zwahlen, 1998; Doerfliger et al., 1999), PI; Protective function of the layers above the saturated zone and the Infiltration conditions (Goldscheider et al., 2000), COP (Vias et al., 2006); SINTACS PRO KARST is an adaption of the original SINTACS in which the score values for each parameters are changed on the basis of different types of karst found in each specific area (Cucchi et al., 2004); RISKE; Rock, Infiltration, Soil, Karst and Epikarst (Petelet-Giraud et al., 2000); RISKE2 (Plagnes et al., 2005); KARSTIC (Davis et al., 2002); REKS; Rocks, Epikarst, Karstification and Soil cover (Malik and Svasta, 1998); PaPRIKa (Kavouri et al., 2011); COP + K; Concentration of flow, Overlying layers, Precipitation regime and Karst saturated zone. (Vias et al., 2006; Andreo et al., 2009); The Slovene Approach (Ravbar, 2007; Ravbar and Goldscheider, 2007); and, integrative vulnerability assessment in karst areas (Butscher and Huggenberger, 2009).

Residents of the western territories of Iran, which are mainly covered with carbonate rocks, are utilizing karst aquifers to supply their rural and urban water demands. In this region, karst water is a vital source for drinking, agricultural and industrial usage. However, to date, no practical strategies have been established for either karst water protection or vulnerability mapping.

Kermanshah, a province in western Iran, in which 35\% of the area is underlain by carbonate formations, is a remarkable example of an area that is strongly dependent on karst water resources. Despite the fundamental impact of these resources on socio-economic and cultural development of the region, no systematic evaluation has been carried out to classify and manage the karstic formations throughout the region. Some research has been conducted on hydrogeology of the aquifers within a number of academic masters theses, doctoral dissertations, and local reports; however, there are still no reliable base maps of karst hydrogeology. Lack of proper data on karst formations, geomorphology, epikarst thickness, karst network development and other infrastructural information of this type has made it more difficult to establish an inclusive pattern for water budget estimation in this region.

This study attempts to introduce a new method for vulnerability mapping of karst aquifers using the limited data available for Kermanshah. Table 1 presents the main

Table 1. Methods and parameters used for the groundwater vulnerability assessment (modified after Polemio et al., 2009).

\begin{tabular}{|c|c|c|c|c|c|c|}
\hline & \multicolumn{6}{|c|}{ Method } \\
\hline Parameter & 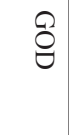 & 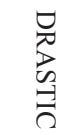 & $\begin{array}{l}\Omega \\
Z \\
Z \\
\Omega \\
\Omega \\
Z\end{array}$ & $\frac{\mathbb{3}}{\vec{\pi}}$ & $\Xi$ & 哥 \\
\hline Topographic slope & & $\mathrm{X}$ & $\mathrm{X}$ & $\mathrm{X}$ & $\mathrm{X}$ & $\mathrm{X}$ \\
\hline Stream network & & & $\mathrm{X}$ & & $\mathrm{X}$ & \\
\hline Characteristics of soils & & $\mathrm{X}$ & $\mathrm{X}$ & $\mathrm{X}$ & $\mathrm{X}$ & \\
\hline Net recharge & & $\mathrm{X}$ & $\mathrm{X}$ & $\mathrm{X}$ & $X$ & \\
\hline $\begin{array}{l}\text { Characteristics of } \\
\text { unsaturated zone }\end{array}$ & $\mathrm{X}$ & $\mathrm{X}$ & $\mathrm{X}$ & $\mathrm{X}$ & $\mathrm{X}$ & $\mathrm{X}$ \\
\hline Hydraulic head & $\mathrm{X}$ & $\mathrm{X}$ & $\mathrm{X}$ & & & \\
\hline Hydrogeological features & $\mathrm{X}$ & $\mathrm{X}$ & $\mathrm{X}$ & $\mathrm{X}$ & & \\
\hline Hydraulic conductivity & & $\mathrm{X}$ & $\mathrm{X}$ & & & \\
\hline Aquifer thicknes & & & $\mathrm{X}$ & & & \\
\hline Land use & & & $\mathrm{X}$ & $\mathrm{X}$ & $\mathrm{X}$ & \\
\hline Lithology & & & & & & $\mathrm{X}$ \\
\hline Elevation & & & & & & $\mathrm{X}$ \\
\hline
\end{tabular}


parameters used in several groundwater vulnerability mapping methods. In the case of Kermanshah's karst area, data for the ordinary vulnerability mapping are either unavailable or unreliable (with low resolution).

\section{Study Area}

Kermanshah is located in the west of Iran with an area of $25,009 \mathrm{Km}^{2}$ and a population of more than 2 million. This region is greatly dependent on karst water resources for drinking and other major demands, such as agriculture, industry and ecotourism. The study area is located in the Zagros zone. This zone is divided into three sub-zones including High Zagros (HZ), Folded Zagros (FZ) and Sanandaj-Sirjan (SS). The major parts of the karst covered areas in the south-western, eastern and south-eastern parts of Kermanshah, are laid in the FZ zone while western and north-western part of the region falls into the $\mathrm{HZ}$ zone. The other part of the study area, with no remarkable karst development, is located in the SS zone. Three types of aquifers have been detected in Kermanshah: alluvial or porous, karst and hard rock. Hard rock aquifers have been poorly studied so far and there is a considerable lack of data for recharge estimation through the study area. Alluvial and karst aquifers have covered 3,613 and $6,575 \mathrm{~km}^{2}$, respectively.

The main source of drinking water is pumping from deep-water wells in karst/porous aquifers or from karst springs. Karst aquifers are Mesozoic to Oligo-Miocene aged carbonate rocks such as Ilam, Sarvak, Asmari, Talezang and Bisetoun formations (Figure 1). Regardless of the geologic formations and their ages, karst terrains of the region could be classified into two main categories (based on their surficial soil cover thickness): buried karst and bare karst. In the buried karst, the carbonate/ evaporate formations are underlain by a reasonable thickness (10-150m) of Quaternary sediments while, in the bare karst, there is no soil cover overlying the karst formations. From the karst protection point of view, buried karsts are significantly more protected against

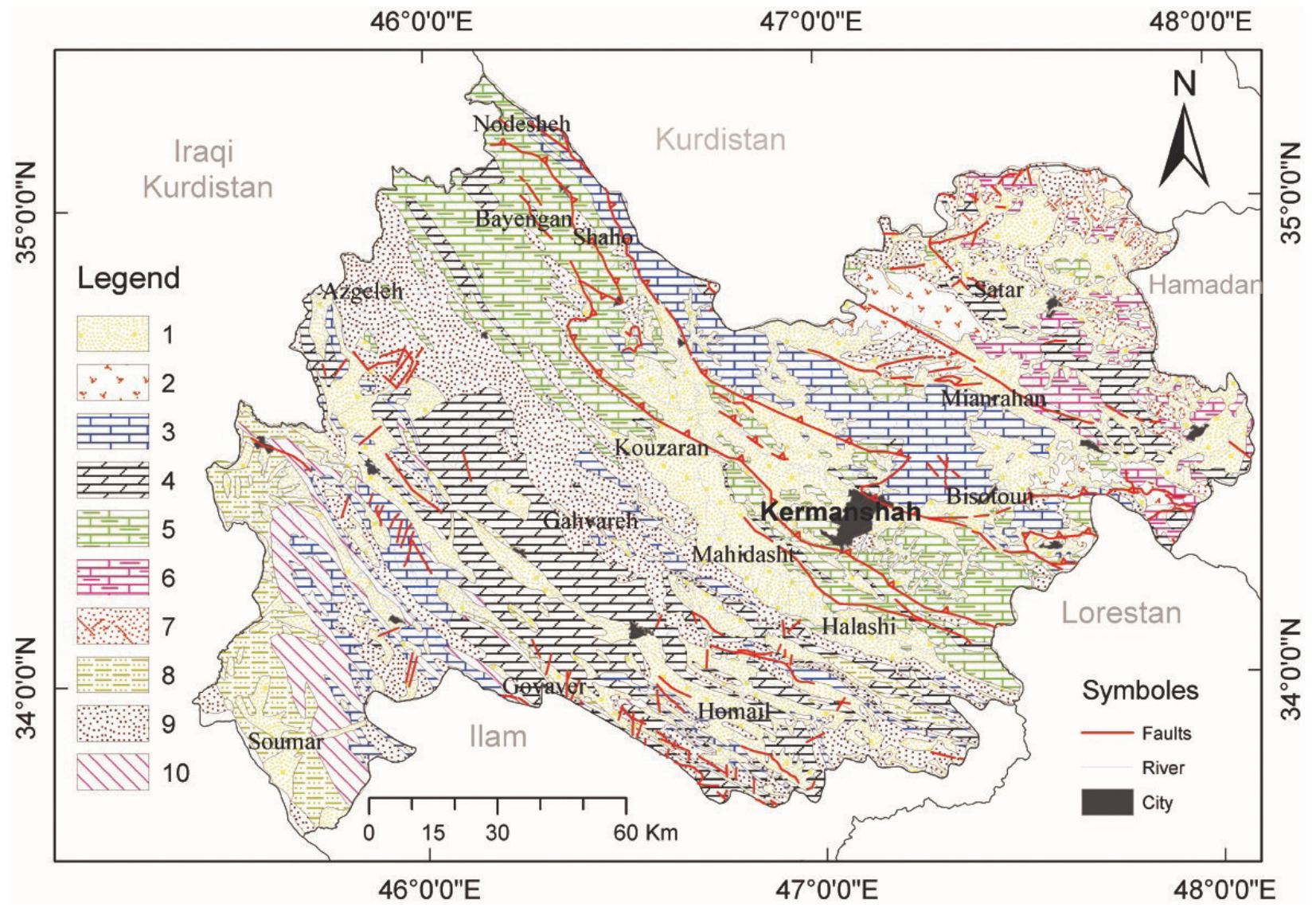

Figure 1. Simplified geological map of Kermanshah; 1: alluvium, 2: volcanic rocks, 3: limestone, 4: dolomitic limestone, 5: marly limestone, 6: metamorphic limestone, 7: volcano-metamorphics, 8: marl, 9: sandstone. and 10: gypsum. 
environmental and anthropogenic pollutant sources than the bare karst. This is because of the ability of soil covers to remove/reduce the pollutants from the downward sinking waters. However, there are still some concerns related to overexploitation activities threatening these kinds of aquifers.

The southwestern part of Kermanshah is located in a semiarid climatic zone, while the other areas (i.e., northwest, east and north) fall into the cold climate category. The mean annual precipitation of these regions is about 500 $\mathrm{mm}$ (up to $800 \mathrm{~mm}$ in higher altitudes). In the Parau and Shahu Mountains, there are several swallow holes, vertical shafts and sinkholes located in altitudes higher than 2,000 $\mathrm{m}$ above sea level (a.s.1.). Snow melting in the high karst plateau is the main source feeding the lowland springs. These springs mainly emerge at the contact areas between the karst formations and non-karst rocks. In some cases, these springs have a considerably high discharge, i.e., Bel spring in the north-western region of Kermanshah with a mean annual discharge of about $5 \mathrm{~m}^{3} / \mathrm{s}$. In this province, relatively impervious radiolarites underlying the carbonate formations have impeded the rate of downward flow of water, forcing it to continue along the contact surface between the two rock units. This process consequently creates a large number of contact springs throughout the region. These springs, which sometimes have large sizes and discharge rates, are called Saraw or Sarab in Kurdo-Persian and local dialect.

The results of a limited number of dye tracing methods showed that there is most often a hydraulic connectivity between highland karsts with lowland discharge points. On the other hand, annual precipitation has a significant effect on the discharge of large springs like Ravansar spring. The quick response of these karstic springs to the precipitation changes can sometimes increase the muddiness of their output flows. Accordingly, conduit-diffuse flow systems are present in mid to large size springs, while the smaller ones often follow a diffuse flow regime. Despite a great number of manmade dams of different sizes throughout the province, karst springs are still serving as a major source of drinking water, especially in rural areas. The main concern about these valuable yet vulnerable sources of water in Kermanshah is the absence of comprehensive studies on karst vulnerability mapping and protection programs.

\section{Methodology}

\section{LEPT Method}

The acronym LEPT stands for a methodology based on four parameters that could be utilized for karst vulnerability mapping in regions with sparse data. The LEPT method is comprised of four initial data layers: Lithology (karstic rocks); Elevation (sinkhole distribution based on the high karst plateau elevation); Protective cover; and, Topographical slope maps. LEPT as well as EPIK (Doerfliger and Zwahlen, 1998) and DRASTIC (Aller et al., 1987) are all multi-attribute weight-rating approaches (overlay and index method). Sinkholes distribution is mainly controlled by elevation and lithology. The protective cover and topographical slope affect groundwater movement into and through karst aquifers. Primary factors of the LEPT model are elevation classification related to sinkhole distribution and the intensity of karstification in carbonate formations. The final karst vulnerability map is computed using the Equation 1;

$$
\mathrm{V}=4 \mathrm{~L}+3 \mathrm{E}+2 \mathrm{P}+\mathrm{T}
$$

Where V: karst vulnerability; L: Lithology; E: Elevation; P: Protective cover; and T: Topographical slope.

\section{Lithology}

The digitized lithology of the 1:250,000 geology map of Kermanshah (Braud, 1978) was used to provide one of the layers for the model. By using this map, Kermanshah's karst formations were divided into three classes based on their intensity of karstification, density of karst springs (number/ $\mathrm{Km}^{2}$ ) and limestone purity. In this classification scheme, the highly developed karst area receives the highest value of 3 , while medium and low/non karst developed formations are assigned the values of 2 and 1, respectively (Figure 2). The higher the value, the higher the vulnerability to karst development would be and vice versa. Mean microscopic porosity of the carbonate formations (obtained from thin section analysis), results of in-situ permeability tests, karst spring density and discharge rate and log observations from drilled boreholes through karstic formations are the main lithological subfactors utilized in the LEPT evaluation method. The subcategories of these parameters are summarized in Table 2 . 


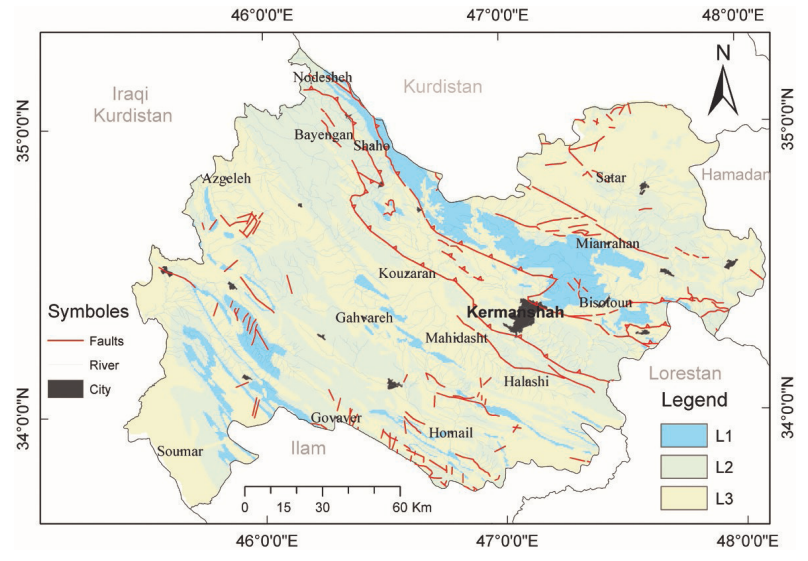

Figure 2. Lithology (L) map estimated for Kermanshah province.

\section{Elevation (Sinkhole Distribution Based on High Plateau Karst Elevation)}

Sinkholes are amongst the most well-known features of karst terrains. These landforms have a great variety of sizes and distribution patterns in the high altitudes of Zagors Mountains. The swallow holes, sinkholes and vertical shafts are main paths of flow concentration within the karst systems. Based on the study conducted by Ghorbani and Mahmoudi (2010), the snow lines of the Kermanshah Mountains have been uplifted from $1,800 \mathrm{~m}$ (a.s.1.) in the Quaternary to 2,500-3,500 m (a.s.l.) at the present time. As a result of this study, Kermanshah karst lands were divided into three classes based on their elevation. Higher elevations have more potential for karst development. Therefore, karst lands with elevations higher than $3,000 \mathrm{~m}$ fall into class 1 (with a value of 3 ), those with elevations between 2,000 to $3,000 \mathrm{~m}$ fall into class 2 with a score of 2 and the others with elevations lower than $2,000 \mathrm{~m}$ are categorized as class 3 , with a score of 1 (Table 2 and Figure 3).

\section{Protective Cover}

The classification for the protective cover is simpler than the other factors. In this category there are just two main classes: class 1, in which no protective soil cover overlies the carbonate formations (receives a value of 2) and class 2, with thin to moderate thickness of sedimentary layers covering the carbonate formations (receives a value of 1) (Figure 4).

It should be noted that, in susceptibility zoning of the karst areas pursued in this study, epikarst and protective (soil) cover layers were considered as a single category.
Table 2. Attribute classes for the lithology $(L)$, elevation (E), protective cover (P) and topographical slope (T).

\begin{tabular}{|c|c|c|c|c|c|}
\hline \multicolumn{4}{|c|}{ Acronym /Characterization } & \multirow{2}{*}{ 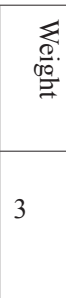 } & \multirow{2}{*}{ 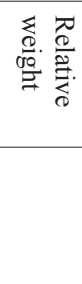 } \\
\hline \multirow[t]{3}{*}{ 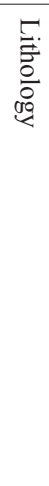 } & $\begin{array}{l}\text { Highly } \\
\text { karst } \\
\text { developed }\end{array}$ & L1 & $\begin{array}{l}\text { Pure limestones } \\
\text { and dolomite }\end{array}$ & & \\
\hline & $\begin{array}{l}\text { Moderately } \\
\text { karst } \\
\text { developed }\end{array}$ & $\mathrm{L} 2$ & $\begin{array}{l}\text { Marly limestone, } \\
\text { gypsum }\end{array}$ & 2 & \multirow{2}{*}{4} \\
\hline & $\begin{array}{l}\text { Poor } \\
\text { karstified or } \\
\text { non-karst }\end{array}$ & L3 & $\begin{array}{l}\text { Sandstone, Marl, } \\
\text { Crystalized } \\
\text { metamorphic } \\
\text { rocks, volcanic } \\
\text { and Quaternary } \\
\text { old deposits }\end{array}$ & 1 & \\
\hline \multirow[t]{3}{*}{ 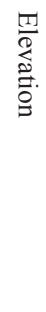 } & $\geq 2500 \mathrm{~m}$ & E1 & $\begin{array}{l}\text { High Sinkhole } \\
\text { density in karst } \\
\text { plateau }\end{array}$ & 3 & \multirow[t]{3}{*}{3} \\
\hline & $\begin{array}{l}2000-2500 \\
\mathrm{~m}\end{array}$ & E2 & $\begin{array}{l}\text { Sinkhole and dry } \\
\text { caves are present } \\
\text { but low density }\end{array}$ & 2 & \\
\hline & $\leq 2000 \mathrm{~m}$ & E3 & $\begin{array}{l}\text { Sinkhole is very } \\
\text { area or absent }\end{array}$ & 1 & \\
\hline \multirow[t]{2}{*}{ 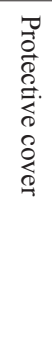 } & Bare lands & $\mathrm{P} 1$ & $\begin{array}{l}\text { Karst lands } \\
\text { without } \\
\text { protective cover } \\
\text { or present a thin } \\
\text { layer of soils }\end{array}$ & 2 & \multirow[t]{2}{*}{2} \\
\hline & $\begin{array}{l}\text { Covered } \\
\text { lands }\end{array}$ & $\mathrm{P} 2$ & $\begin{array}{l}\text { Lands which } \\
\text { covered by thick } \\
\text { layer of soil, } \\
\text { alluvium and } \\
\text { screes. }\end{array}$ & 1 & \\
\hline \multirow{3}{*}{ 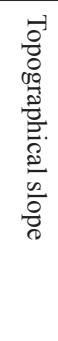 } & $0-10$ & $\mathrm{~T} 1$ & $\begin{array}{l}\text { Gentle dip or flat } \\
\text { lands }\end{array}$ & 3 & \multirow{3}{*}{1} \\
\hline & $10-30$ & $\mathrm{~T} 2$ & $\begin{array}{l}\text { Dip between } \\
10 \text { degree to } 30 \\
\text { degree. }\end{array}$ & 2 & \\
\hline & $\geq 30$ & $\mathrm{~T} 3$ & $\begin{array}{l}\text { Highly slope } \\
\text { lands with } \\
\text { some karst and } \\
\text { fractures }\end{array}$ & 1 & \\
\hline
\end{tabular}

Therefore, for further evaluations, geological and soil distribution maps were utilized. Considering the data extracted from the geological maps of the study area, the thickness of the soil cover (wherever there is a soil cover) is always greater than $1 \mathrm{~m}$. This, then, gives all the soil-covered areas a value of 2 in the final classification processes. 


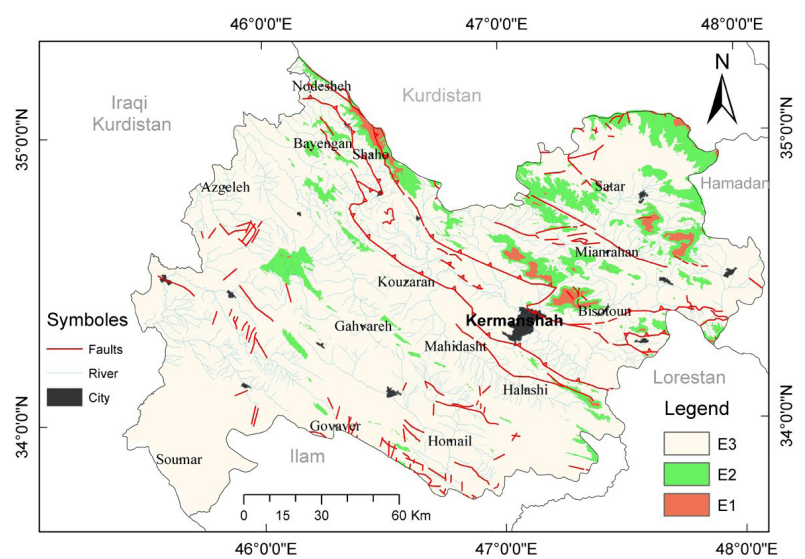

Figure 3. Elevation (E) map estimated for Kermanshah.

\section{Topographical Slope}

Surface topography has an effect on the rate of water infiltration and migration into and through karst aquifers. This feature is divided into three classes using surface slopes. According to this classification, lands with slope angles between $0 \%$ to $10 \%, 10 \%$ to $30 \%$ and greater than $30 \%$ are given values of 3, 2, and 1, respectively (Figure 5).

\section{Mapping of LEPT}

The final vulnerability map based on the LEPT index (Vl) was obtained by multiplying the defined coefficients (Eq. 1) by the individual map layers (L, $\mathrm{E}, \mathrm{P}$, and T maps) on a grid map (cells of $200 \mathrm{~m} \times 200$ $\mathrm{m})$ in GIS. After performing the above mentioned calculation, the produced maps were overlaid (weighted sum-spatial analysis in ArcMap).

The result of this process presents the final vulnerability map of the region. The final LEPT

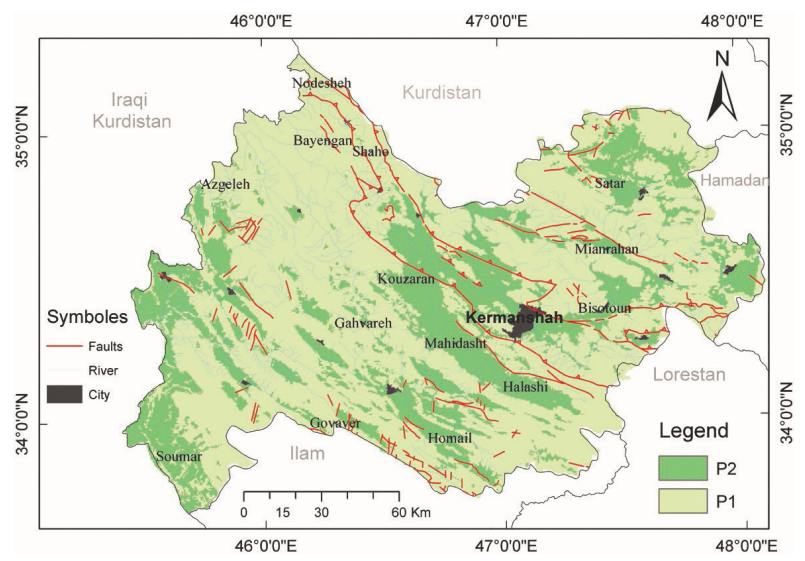

Figure 4. Protective cover (P) map estimated for Kermanshah.

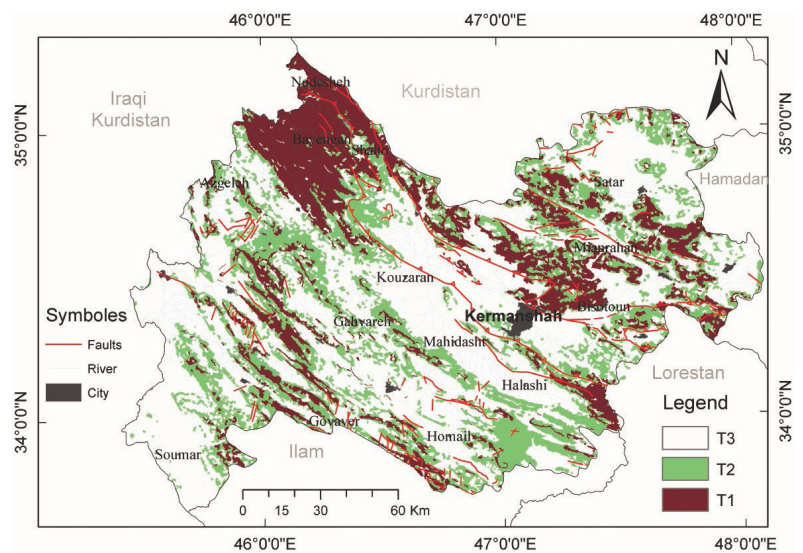

Figure 5. Topographical slope (T) map estimated Kermanshah.

map was then subdivided into three categories in accordance with the degree of vulnerability of each factor/layer based on Natural break criterion in the GIS environment. The natural break classification method has commonly been used in landslide susceptibility mapping to categorize the susceptibility classes (Falaschi et al., 2009; Bednarik et al., 2010; Pourghasemi et al., 2013) and sinkhole susceptibility mapping (Taheri et al., 2015).

\section{Sensitivity Analysis}

A "Map removal" and "Single parameter" sensitivity analyses are two common sensitivity tests for some of the parametric methodologies such as DRASTIC, EPIK, PaPRIKA and so forth. The Map removal sensitivity was performed by Lodwick et al. (1990) and the single parameter was introduced by Napolitano and Fabbri (1996). Sensitivity of removing one or more maps can be expressed as (Lodwik et al., 1990; Gogu and Dassargues 2000):

$$
\mathrm{S}=100(\mathrm{~V} / \mathrm{N}-\mathrm{vx} / \mathrm{n}) / \mathrm{V}
$$

Where $\mathrm{S}$ is the sensitivity associated with the removal of one map, $\mathrm{V}$ and $\mathrm{vx}$ are the vulnerability degrees computed by using Eq. 1 without or with considering the parameter $\mathrm{X}$, respectively; $\mathrm{N}$ and $\mathrm{n}$ are the number of data layers used to calculate $\mathrm{V}$ and $\mathrm{v}$.

The single parameter sensitivity test was performed to assess the influence of each of the four parameters of the model on the vulnerability measure. With this approach, the real or effective weight of each parameter could be compared with its allocated or theoretical weight 
(Napolitano and Fabbri, 1996). The real or the effective weight is calculated as follows:

$$
\mathrm{W}=100 . \operatorname{Pr} . \mathrm{PW} / \mathrm{V}
$$

Where W refers to the "effective" weight of each parameter, Pr and Pw are the value and weight for each parameter, and $\mathrm{V}$ is the overall vulnerability index calculated using Eq. 1.

\section{Result and Discussions}

The karst vulnerability map of Kermanshah (Figure 6) was made by overlaying the four parameters of the LEPT method through raster analysis in GIS. The results show an area of very high vulnerability that covers 2,094 $\mathrm{km}^{2}$ of Kermanshah ( $8.4 \%$ of the study area). This area is distinguished by its remarkable sinkholes, shafts, caves and other active karst landscapes. Snow melting during spring is the main source for large karst springs feeding into lowlands. Due to the preferential drainage in sinkholes and other open karst landscapes in it, this zone is very sensitive to contamination. Parau, a famous cave in the region, and Shahu, a karst plateau, are both located in this zone.

High and very high vulnerable areas cover $6,400 \mathrm{~km}^{2}$ of the study area, equal to $25.6 \%$ of Kermanshah's total area. The dry caves and karren fields which were developed during the Quaternary by fluvial karstification are some of the main features of these areas. Many caves and large springs are located in this zone.

A Low vulnerable area comprises $6,540 \mathrm{~km}^{2}$ or $26 \%$ of the study area. This zone is characterized by karstified formations developed at the contact of a non-karstified area and Quaternary deposits.

A Very low or none vulnerable area covers approximately $40 \%$ of the entire province, with an area of $9,974 \mathrm{~km}^{2}$. The results of the map removal sensitivity analysis are shown in Table 3.

Results show that the relative influence on the final LEPT map is $\mathrm{E}>\mathrm{L}>\mathrm{P}>\mathrm{T}$. On the final map, the statistical

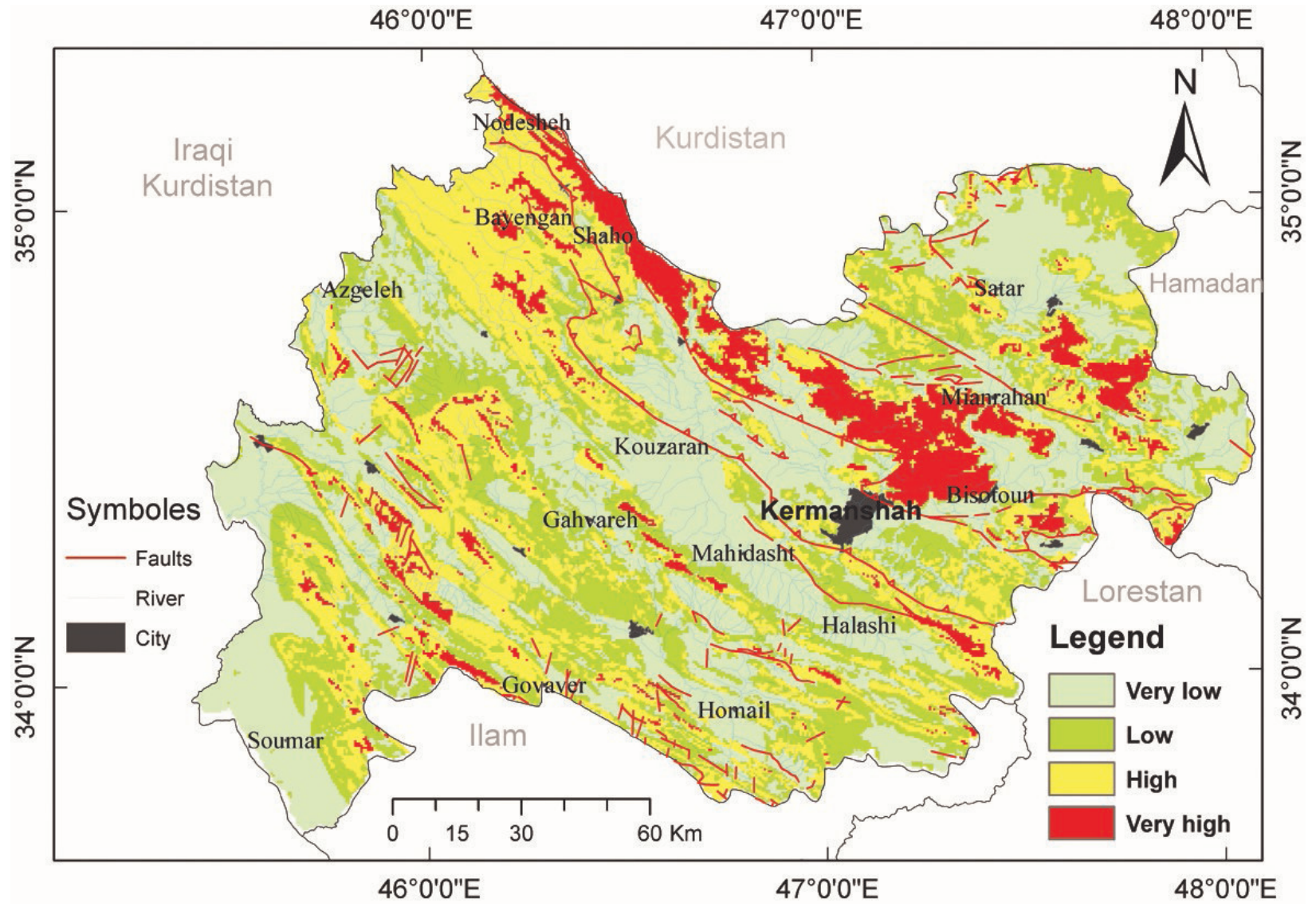

Figure 6. Final map of Kermanshah karst vulnerability. 
Table 3. Statistics of map removal sensitivity analysis.

\begin{tabular}{|l|l|l|l|l|l|}
\hline P & Av. & Std(\%) & Med. & Min. & Max. \\
\hline L & 4.54 & 4.33 & 9 & 0 & 16 \\
\hline E & 22.4 & 1.93 & 22 & 18 & 25 \\
\hline P & 1.6 & 2.99 & 6.5 & 0 & 11 \\
\hline T & 4.98 & 3.74 & 6 & 0 & 10 \\
\hline
\end{tabular}

P: Parameter; Av: Average (\%); Std. (\%): standard deviation; Med: Median (\%); Min: Minimum (\%); Max: Maximum (\%)

Table 4. Statistics of single parameter sensitivity analysis.

\begin{tabular}{|l|l|l|l|l|l|l|l|l|}
\hline \multirow{2}{*}{$\mathrm{P}$} & \multirow{2}{*}{ TW } & \multirow{2}{*}{$\begin{array}{l}\text { TW } \\
(\%)\end{array}$} & \begin{tabular}{l} 
Av. \\
\cline { 4 - 9 }
\end{tabular} & $\begin{array}{l}\text { Std. } \\
(\%)\end{array}$ & Med. & Min & Max & RW \\
\hline L & 4 & 40 & 41.23 & 8.56 & 41 & 20 & 66 & 1.03 \\
\hline E & 3 & 30 & 23.44 & 6.39 & 30.5 & 12 & 60 & 0.78 \\
\hline P & 2 & 20 & 23.52 & 5.31 & 18.5 & 9 & 33 & 1.17 \\
\hline T & 1 & 10 & 10.95 & 3.84 & 13.5 & 3 & 30 & 1.09 \\
\hline
\end{tabular}

P: Parameter; TW: Theoretical Weight; TW(\%):Theoretical Weight in percentage (\%) ;Av: Average(\%); Std.(\%): standard deviation; Med: Median(\%);Min: Minimum(\%); Max: Maximum(\%) and RW: Real weighting

parameters (Table 3) show that elevation (E) is the parameter with the highest sensitivity. Accordingly, the $\mathrm{L}$ parameter has the second highest value due to its high rating and weighting. The LEPT method is also sensible to remove the $(\mathrm{P})$ parameter because this presents a vast spatial distribution. The (T) parameter is similar to the $\mathrm{P}$ parameter. These results are logically acceptable because, based on the distribution of sinkholes on the high karst plateau, the parameter $\mathrm{E}$ is playing an important role in dispersing the contaminants.

The single parameter sensitivity analysis indicates that the lithology parameter (L) dominates the vulnerability index with an average weight of $41.23 \%$ versus the theoretical weight of $40 \%$. Due to its very influential effect on final output of the model, the high sensitivity of the L parameter was expected (Table 4). This dominance has been clearly seen throughout the study area. On the other hand, the real weight of parameter E $(23.44 \%)$ is notably smaller than its theoretical weight (30\%). It means that the actual influence of this parameter within the study area is lower than what was estimated based on Eq. 1.
On the other hand, the real weights of parameters $\mathrm{P}$ and T with respectively $23.52 \%$ and $10.92 \%$ are greater than their corresponding theoretical weights of $20 \%$ and $10 \%$. Therefore, it is important to have these data compared in order to produce a reliable final output map.

\section{References}

Adams B, Foster SSD. 1992. Land-surface zoning for groundwater protection. Water and Environment Journal 6 (4): 312-319.

Albinet M, Margat J. 1970. Cartographie de la vulnerabilit'e a la pollution des nappes d'eau souterraine [Contamination vulnerability mapping of groundwater]. Bulletin de la Bureau de Recherches G'eologiques et Mini'eres 2nd serves 3 (4): 13-22.

Aller L, Bennett T, Lehr JH, Petty RJ. 1987. DRASTIC: a standardized system for evaluating ground water pollution potential using hydrogeological settings. US Environmental Protection Agency, Oklahoma.

Andreo B, Ravbar N, Vias JM. 2009. Source vulnerability mapping in carbonate (karst) aquifer by extension of the COP method: application to pilot sites. Hydrogeology Journal 17: 749-758.

Bednarik M, Magulova B, Matys M, Marschalko M. 2010. Landslide susceptibility assessment of the Kralovany-Liptovsky Mikulas railway case study. Phys Chem Earth Parts A/B/C 35 (3-5): 162-171.

Braud J. 1978. Geological map of Kermanshah at 1/250.000 scale. Geological survey of Iran.

Butscher C, Huggenberger P. 2009. Enhanced vulnerability assessment in karst areas by combining mapping with modeling approaches. Science of the Total Environment Journal 407: 1153-1163.

Civita M. 1994. Aquifer Vulnerability maps to pollution, Pitagora Ed., Bologna.

Cucchi F, Forti P, Zini L. 2004. The vulnerability of complex karst hydrostructures: problems and perspectives. Geofisica Internacional 43 (4), 85 93.

Daly D, Dassargues A, Drew D, Dunne S, Goldscheider N, Neale S, Popescu C, Zwhalen F. 2002. Main concepts of the "European approach" to karstgroundwater-vulnerability assessment and mapping. Hydrogeology Journal 10 (2): 340-345.

Davis A, Long A, Wireman M. 2002. KARSTIC: a sensitivity method for carbonate aquifers in karst terrain. Environmental Geology 42 (1): 65-72.

Doerfliger N, Zwahlen F. 1998. Groundwater vulnerability mapping in karstic regions (EPIK) - application to groundwater protection zones. Swiss Agency for the Environment, Forests and Landscape (SAEFL), Bern. 
Doerfliger N, Jeannin PY, Zwahlen F. 1999. Water vulnerability assessment in karst environments: a new method of defining protection areas using a multi-attribute approach and GIS tools (EPIK method). Environ Geol 39 (2): 165-176

Drew D, Hotzl H (editors). 1999. Karst Hydrogeology and Human Activities Impacts, Consequences and Implications. International Contributions to Hydrogeology (IAH) 20. Balkema, Rotterdam.

European Commission. 2000. Directive 2000/60/EC. European water framework directive for European water management establishing a framework for community action in the field of water policy.

Falaschi F, Giacomelli F, Federici PR, Puccinelli A, D’Amato AG, Pochini A, Ribolini A. 2009. Logistic regression versus artificial neural networks: landslide susceptibility evaluation in a sample area of the Serchio River valley, Italy. Nat. Hazards 50: 551-569.

Foster SSD. 1987. Fundamental concepts in aquifer vulnerability, pollution risk and protection strategy. In: Van Duijevenboden W, Van Waegeningh HG, editors. Vulnerability of soil and groundwater to pollutants 38 . TNO Committee on Hydrogeological Research, Proceedings and Information, The Hague, p. 69-86.

Foster S, Hirata R. 1988. Groundwater pollution risk assessment: a methodology using available data. WHO-PAHO-CEPIS, Lima.

Ghorbani MS, Mahmoudi F. 2010. The role of karstic landforms in the evolution of Shaho highe karst plateaue, northwest of Kermanshah. In: Taheri K, Raeisi E, editors. Geology, Hydrogeology \& Engineering of Karst Resources of Iran, Proceedings of The First Iranian National Conference on Applied Research in Water Resources, Kermanshah, Iran. p. 300-312.

Gogu RC, Dassargues A. 2000. Sensitivity analysis for the EPIK method of the vulnerability assessment in a small karstic aquifer, southern Belgium. Hydrogeology Journal 8: 337-345.

Goldscheider N. 2005. Karst groundwater vulnerability mapping: application of a new method in the Swabian Alb, Germany. Hydrogeology Journal 13 (4): 555-564.

Goldscheider N, Popescu C. 2004. The European approach. In: Zwahlen F, editor. Vulnerability and risk mapping for the protection of carbonate (karst) aquifers. European Commission, Brussels, p. 17-21.

Goldscheider N, Klute M, Sturm S, Hötzl H. 2000. The PI method - a GIS- based approach to mapping groundwater vulnerability with special consideration of karst aquifers. Zeitschrift fur Angewandte Geologie 46 (3): 157-166.
Kavouri K, Plagnes V, Tremoulet J, Dörfliger N, Rejiba F, Marchet P. 2011. PaPRIKa: a method for estimating karst resource and source vulnerability - application to the Ouysse karst system (southwest France). Hydrogeology Journal 19 (2): 339-353.

Lodwik WA, Monson W, Svoboda L. 1990. Attribute error and sensitivity analysis of map operations in geographical information systems-suitability analysis. Int J Geog Inf Sist 4: 413-428.

Malík P, Švasta J. 1998. Mapy zranitel'nosti podzemných vôd pre oblasti krasovo-puklinových a puklinových kolektorov. (Groundwater vulnerability maps for the areas with karst-fissure and fissure aquifers, in Slovak). Manuscript, Archive of the Geological Survey of Slovak Republic.

Margat J. 1968. Vuln_rabilit_des nappes d'eau souterraine la pollution (Vulnerability of groundwater to pollution). BRGM Publication 68 SGL 198 HYD, Orleans.

Napolitano P, Fabbri AG. 1996. Single-parameter sensitivity analysis for aquifer vulnerability assessment using DRASTIC and SINTACS. HydroGIS 96: Application of Geographic Information Systems in Hydrology and Water Resources Management (Proceedings of the Vienna Conference, April 1996). IAHS Publ 235: 559-556.

Petelet-Giraud E, Doerfliger N, Crochet P. 2000. RISKE: method d'evaluation multicritre de la cartographie de la vulnerabilite des aquiferes karstiques. Application aux systemes des Fontanilles et Cent-Fonts karstic aquifers (Hérault, S. France). Hydrogéologie 4: 71-88.

Plagnes V, Théry S, Fontaine L, Bakalowicz M, Dörfliger N. 2005. Karst vulnerability mapping: improvement of the RISKE method. KARST 2005, Water Resources and Environmental Problems in Karst, 14-19 September 2005 Belgrade-Kotor, Serbia.

Polemio M, Casarano D, Limoni PP. 2009. Karstic aquifer vulnerability assessment methods and results at a test site (Apulia, southern Italy). Nat Hazards Earth Syst Sci 9: 1461-1470.

Pourghasemi HR, Moradi HR, Fatemi Aghda SM. 2013. Landslide susceptibility mapping by binary logistic regression, analytical hierarchy process, and statistical index models and assessment of their performances. Nat Hazards 69: 749-779.

Ravbar N. 2007. Vulnerability and risk mapping for the protection of karst waters in Slovenia: application to the catchment of the Podstenjšek springs (in English). PhD Thesis, University of Nova Gorica, Slovenia. 
Ravbar N, Goldscheider N. 2007. Proposed methodology of vulnerability and contamination risk mapping for the protection of karst aquifers in Slovenia. Acta Carsol 36 (3): 461-475.

Taheri K, Gutiérrez F, Mohseni H, Raeisi E, Taheri M. 2015. Sinkhole susceptibility mapping using the analytical hierarchy process (AHP) and magnitude-frequency relationships: A case study in Hamadan province, Iran. Geomorphology 234: 64-79.

Van Stempvoort D, Ewert L, Wassenaar L. 1993. Aquifer vulnerability index (AVI): a GIS compatible method for groundwater vulnerability mapping. Can Water Res J 18: 25-37.

Vias JM, Andreo B, Perles MJ, Carrasco F, Vadillo I, Jiménez P. 2006. Proposed method for groundwater vulnerability mapping in carbonate (karstic) aquifers: the COP method Application in two pilot sites in southern Spain. Hydrogeol J 14: 912-925.

Zwahlen F, editor. 2004. Vulnerability and risk mapping for the protection of carbonate (karst) aquifers, EUR 20912. Brussels7 European Commission, Directorate-General XII Science, Research and Development, $297 \mathrm{p}$. 